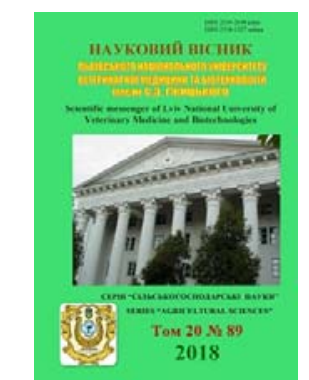

Науковий вісник Дьвівського національного університету ветеринарної медицини та біотехнологій імені С.3. Гжицького

\author{
Scientific Messenger of Lviv National University \\ of Veterinary Medicine and Biotechnologies
}

UDC 639.31.043

\title{
Economic efficiency of growing commodity trout in farms in the Western Ukraine while feeding with forages Aller Aqua
}

\author{
I.Y. Bobel, J.I. Pivtorak, R.A. Petryshak \\ Stepan Gzhytskyi National University of Veterinary Medicine and Biotechnologies Lviv, Ukraine
}

Article info

Received 10.09.2018 Received in revised form 10.10 .2018 Accepted 11.10.2018

Stepan Gzhytskyi National University of Veterinary Medicine and Biotechnologies Lviv, Pekarska Str., 50, Lviv, 79010, Ukraine. Tel.: +38-050-522-86-23 E-mail:irynabobel@gmail.com

Bobel, I.Y., Pivtorak, J.I., \& Petryshak, R.A. (2018). Economic efficiency of growing commodity trout in farms in the Western Ukraine while feeding with forages Aller Aqua. Scientific Messenger of Lviv National University of Veterinary Medicine and Biotechnologies, 20(89), 71-74. doi: $10.32718 /$ nvlvet8913

Fish farming, as an agricultural sector, plays an important role in providing people with valuable food. In order to maintain fish stocks in reservoirs at the industrial level, the introduction of additional industrial species, as well as their hybrid forms, is important. Growing trout is promising in Ukraine, especially in the western region. The urgent task for modern freshwater fish farming in Ukraine is the restoration of effective development of trout fishing. An increase in the production of high-quality trout products in Ukraine will make it possible to significantly reduce imports of salmon fish. According to the working meeting of the trolling development team in Ukraine, held on September 6, trout growing in the Ukrainian market reached 6 thousand tons, while 10 thousand tons per year of grown trout is the absolute minimum that can be grown. In our country trout is not a traditional breeding object, its production is only $1.5 \%$ of all species of fish. The increase in the production trout fishing of products is possible due to the expansion of production areas, the integration of production processes, the transfer of experience from foreign producers, as well as investments in the fishing industry, which would allow small farms to supply domestic products to the market. An important moment in the development of profitable trout farms is the definition of the optimal commodity weight of trout. So in foreign trout fishing, small trout is not realized. Freshwater economies in Germany, Denmark, and Turkey face high feed costs and relatively low productivity. In the US, for example, during the year the trout reaches a mass of 410-450 g; in Japan, rainbow trout weighing 100-120 $\mathrm{g}$ is used as a landing material for garden cultivation in seawater, which is carried out from October to July next year at a water temperature of $8-14{ }^{\circ} \mathrm{C}$. At the end of the period, the fish grown up to $2 \mathrm{~kg}$. Growing rainbow trout as commercial fish in trout farms is organized with different terms of implementation, depending on the different weight of fish. Currently, trout is considered to be commodity in Ukraine with an average weight of 250-350 g. But given the current state of the market of fish products, it is not feasible to sell such fish because it does not show its food and taste preferences and does not have a commodity condition. Along with this, in the commodity trout weighing $500 \mathrm{~g}$ or more, except for meat, caviar are a valuable food product. Fishery productivity is a key indicator of the efficiency of farm fish farming and reflects the state of technology and production culture, and the level of management affects all economic performance of the fish industry. In modern trout fishing, traditional feeds are finally replaced with highly effective granulated dry feed mixes. Therefore, the purpose of our work was, based on a review of literary sources and analysis of the economic activity of the investigated farms, to give a general description of the forage for Aller Aqua, which is used for fish feeding, and to determine their effectiveness.

Key words: rainbow trout, Aller Aqua feed, fish industry, economic efficiency, high-yielding feed, growing technology, trout feed, metabolic processes, diet, growth rate, productive action, feeding standards, feeding plan.

\section{Економічна ефективність вирощування товарної форелі у фермерських господарствах Західної України за умов годівлі кормами Aller Aqua}

\author{
І.Ю. Бобель, Я.І. Півторак, Р.А. Петришак
}

Львівський національний університет ветеринарної медицини та біотехнологій імені С.3. Гжицького, м. Львів, Украӥна 
Рибництво, як галузь сільського господарства, відіграє важливу роль у забезпеченні людей ијнними продуктами харчування. Для підтримання у водоймах запасів риби на промисловому рівні важливе значення має впровадження у виробництво додаткових промислових видів, а також їх гібридних форм. В Украӥні, особливо в Західному регіоні, перспективним є вирощування форелі. Актуальним завданням для сучасного прісноводого рибництва в Україні є відновлення ефективного розвитку форелівництва. Збільшення виробництва високоякісної товарної продукиії форелі в Украӥні дасть можливість істотно скоротити імпорт лососевих риб. За даними робочого засідання групи з розвитку форелівнищтва в Украӥні, щсо відбулось 6 вересня, вирощування форелі на ринку Украӥни досягло 6 тис. тон, у той час, коли 10 тисяч тон на рік вирощеної форелі - це абсолютний мінімум, який легко може вирошуватися. У нашій країні форель не є традиційним об'єктом розведення, обсяг ї̈ виробництва становить лише 1,5\% від усіх видів риб. Нарощування виробництва продукиії форелівництва можливе завдяки розщиренню виробничих площ, інтинсифікації виробничих процесів, запозиченню досвіду у іноземних виробників, а також завдяки інвестиціям у галузь рибництва, щзо дозволило б невеликим фермерським господарствам постачати на ринок продукиію вітчизняного виробництва. Важливим моментом розвитку рентабельних форелевих господарств є визначення оптимальної товарної маси форелі. Так у закордонному форелівництві дрібна форель не реалізується. Прісноводні господарства Німеччини, Даніі, Туреччини стикаються з проблемами високих витрат на корми і порівняно низькою продуктивністю. У США, наприклад, за рік вирошування форель досягає маси 410-450 г; у Японї райдужна форель масою 100-120 г використовується як посадковий матеріал для садкового вирошування у морській воді, яке проводять з жовтня по липень наступного року за температури води 8-14 ${ }^{\circ} \mathrm{C}$. На кінець періоду вирощувана риба досягає 2 кг. Вирощування райдужної форелі як товарної риби у форелевих господарствах організовано із різними строками реалізачії, залежно різної маси риби. На даний час в Україні товарною вважається форель середньою масою 250-350 г. Але з огляду на сучасний стан ринку рибопродукцї реалізувати таку рибу недоцільно, оскільки вона не проявляє свої харчові та смакові переваги та не має товарної кондиції. Поряд з цим, у товарної форелі масою 500 г $і$ більше, крім м'яса цінним харчовим продуктом є ікра. Рибопродуктивність є основним показником, шцо характеризує ефективність роботи фермерського рибного господарства та відображає стан технології $і$ культуру виробництва, а рівень управління впливає на всі економічні показники роботи рибницького господарства. У сучасному форелівництві традиційні корми остаточно замінені на високоефективні гранульовані сухі кормові сумімі. Через те, метою нашої роботи було на підставі огляду літературних джерел $і$ аналізу господарської діяльності досліджуваних господарств дати загальну характеристику кормів для форелі фірми Аllег Аqиа, які використовуюся для годівлі риби, та визначити їх ефективність.

Ключові слова: райдужна форель, корм Aller аqиа, рибна галузь, економічна ефективність, високопродуктивний корм, технологія вирощування, комбікорм для форелі, обмінні процеси, раціон, інтенсивність росту, продуктивна дія, норми годівлі, план годівлі.

\section{Вступ}

Для того щоб добитися найкращих результатів при вирощуванні риби, необхідно здійснити ретельне планування виробництва, підбір необхідного корму і вибір правильної стратегії годівлі. Темп росту риби і ефективність використання кормів - це тісно зв'язані між собою фактори, що оцінюються двома основними показниками: середньодобовий приріст і кормовий коефіцієнт.

На сьогодні вихідним чинником, що забезпечує конкурентоспроможність та прибутковість підприємств протягом тривалого періоду є висока якість та широкий асортимент товарної рибної продукції. Вихід на ринок, зростання, зрілість, насичення і падіння, дають змогу передбачити зміни у смаках споживачів, а також канали розподілу. Показники обсягів реалізації продукції й отриманий прибуток використовують як індикатори, що відображають стадію виробничого циклу. У сучасних економічних умовах якість рибної продукції стала визначальним фактором для успішної іiі реалізації.

Основою високих результатів діяльності рибних господарств є рівень використання об'єкта вирощування, який максимально пристосований до місцевих екологічних умов та технології ведення рибництва.

Використання новітніх високоенергетичних кормів для риби потребує відповідної обережності. Важливими умовами є детальний розрахунок і точна доза при годівлі. Корекцію дози потрібно виконувати протягом 3-5 днів (для личинки і малька - щоденно). Необхідно вести контроль поїдання корму і своєчасно зменшувати раціон в 2-3 рази або повністю зупинити годівлю при погіршенні фізіологічного стану риби і підвищеному відході (Pivtorak and Bobel, 2018).
Був використаний сухий гранульований корм 3 вмістом сирого протеїну 36,5 , жиру - 16,5, вуглеводів $-27,5$, волога - 10,5\%. Енергетична цінність корму 3260 ккал/кг обмінної енергії. Добова норма була близька до норми годування до повного насичення. При згодовуванні основної дози, що залежить від маси риби і температури води, користувалися кормороздавачем, ввечері вручну видавали останню дозу корму.

Необхідно здійснити підбір правильного розміру крупок і гранул, що повинен буди доступний рибам відповідно до їхнього розміру та маси.

Важливою умовою $є$ здійснення кормових даванок відповідно до температури води.

На початкових етапах годівлі використовували стартові корми, надалі продукційні корми, що згодовувались у тій кількості, що необхідна відповідно до маси риби, температури та величини гранул.

Актуальність теми базується на тому, що основним питанням ефективності аквакультури є використання повноцінних комбікормів, вартість яких становить більше $60 \%$ від суми затрат на цей вид діяльності. Тому питання забезпечення повноцінними комбікормами форелеві господарства, є однією з основних проблем, яка визначає економічну ефективність розвитку аквакультури.

Mета $i$ завдання дослідження полягали в оцінці економічної ефективності вирощування форелі у досліджуваних господарствах та здійсненні порівняльної характеристики раціональності вирощування форелі за умов годівлі кормами Aller Aqua.

\section{Матеріал і методи досліджень}

Питання годівлі форелі є однією із найважливіших умов іiі вирощування. Від того, наскільки правильно 
встановлено режим годівлі, залежить робота всього господарства. Природна їжа в переважній більшості випадків вирощування форелі в спеціально створених водоймах не відіграє особливого значення. Всі необхідні поживні речовини, мікроелементи та вітаміни форель отримує із згодованих кормів (Bozhyk et al., 2004; Martseniuk, 2008; Brinker et al., 2016).

Дослідження проводили протягом 2016-2017 pp. на базі господарств “Західна рибна компанія” Перемишлянського р-ну, Львівської області та “Рибний потік” Рахівського р-ну, Закарпатської області. Досліджуваний період тривав 12 міс. Досліджувані господарства $є$ повносистемними, вирощування риби здійснюється від інкубаціїі ікри до отримання личинок, мальків та товарної риби.

Матеріалом для досліджень були усі вікові групи форелі від личинки до товарної продукції.

Всі отримані в процесі досліджень дані статистично обробляли за стандартними методиками на комп'ютері за програмою Microsoft Excel та Statistica 6.0. (Mamchych, 2006). Основні рибогосподарські дослідження були проведені за методиками, загальноприйнятими у рибництві. Окрім цього, ми провели аналіз різних видів кормів для різновікової форелі.

\section{Результати та їх обговорення}

Істотний розвиток ставового рибництва та підвищення його ефективності можливе тільки при комплексному застосуванні всіх інтенсифікаційних заходів, пов'язаних, як 3 підвищенням технологічного рівня так і з вдосконаленням всіх елементів організаціï, а найбільш швидкий економічний шлях розвитку - це широке впровадження сучасного досвіду кращих господарств.

\section{Таблиця 1}

Економічна ефективність вирощування товарної форелі

\begin{tabular}{|c|c|c|}
\hline Показники & $\begin{array}{c}\text { Кількість продукції (витрат) } \\
\text { на господарстві №1 }\end{array}$ & $\begin{array}{c}\text { Кількість } \\
\text { продукції (витрат) на } \\
\text { господарстві №2 }\end{array}$ \\
\hline $\begin{array}{l}\text { Період вирощування до товарної } \\
\text { продукції } 320-350 \text { г, міс. }\end{array}$ & 12 & 12 \\
\hline Вихід товарної продукції, \% & 80 & 55 \\
\hline Товарна риба, ц & 345,6 & 180,5 \\
\hline тис. шт & 115,2 & 55,4 \\
\hline Собівартість 1 ц продукції, грн & 7483 & 7235,7 \\
\hline Середня реалізаційна ціна 1 ц товарної продукції, грн & 13500 & 11000 \\
\hline $\begin{array}{l}\text { Затрати на вирощування : } \\
\text { - корми Aller aqua за } 1 \text { кг, грн }\end{array}$ & 50,3 & 50,3 \\
\hline Закупівля ікри 100 тис. шт., грн & 55500 & 55500 \\
\hline На всю вирощену рибу кількість корму, кг & 38707,2 & 18500 \\
\hline Кількість грн. за всі корми, грн & 1946972,16 & 930550 \\
\hline Всього затрат на вирощування, грн & 2586124,8 & 1306035,1 \\
\hline Прибуток від реалізаційної риби, грн & 4665600 & 1985500 \\
\hline Чистий прибуток, грн & 1400359,06 & 679399 \\
\hline Рентабельність виробництва, \% & 54,15 & 52,02 \\
\hline
\end{tabular}

Підрощування тривало протягом 5 місяців, до того часу, поки мальок не набув індивідуальної маси в межах 40 г потім рибу пересадили у басейни, де ви-
Ефективність виробництва - узагальнююча категорія, якісна характеристика якої відображається у високій результативності використання живої і уречевленої праці в засобах виробництва.

Враховуюче вище сказане, ми в своїй роботі здійснювали економічну оцінку технології вирощування форелі в рибгосподарствах Передкарпаття та Закарпаття враховуючи всі технологічні етапи від закладки ікри до одержання товарної продукції. Для економічної оцінки нами використані наступні показники:

- вихід продукції з 1 га водного дзеркала;

- собівартість 1 ц риби;

- реалізаційна ціна 1 ц риби;

- валовий дохід від реалізації;

- рентабельність.

У даному випадку рівень інтенсифікаційних заходів у порівнюваних господарствах приблизно однаковий і не впливає на різницю у рибопродуктивності.

При організації годівлі риби кормами Aller aqua необхідно врахувати, що забороняється нормування годівлі відповідно до даних отриманих методом спостереження, тобто відповідно до поїдання корму, оскільки це може привести до переїдання і відходу риби (Pivtorak et al., 2017).

Поживні речовини, що містяться в кормі, повинні не тільки підтримувати життєдіяльність організму, але i сприяти його росту (Hrynzhevskyi et al., 2002). 3 точки зору енергетичної цінності найбільш важливими компонентами корму є протеїн, жир і вуглеводи.

Поряд з білками, жирами і вуглеводами важливе значення для підтримки життєвих функцій мають вітаміни і мінеральні речовини. Якщо будь-яка необхідна речовина відсутня або міститься в кормі в недостатній кількості, то це перешкоджає нормальному функціонуванню організму (Pivtorak and Bobel, 2017). рощували на товарну продукцію. Процес вирощування тривав 210 днів, 7 місяців і на квітень риба досягла маси 320-350 г. 
Висока якість та широкий асортимент товарної рибної продукції задовольняє потреби споживачів і $є$ вихідним чинником, що забезпечує конкурентоспроможність та прибутковість підприємств протягом тривалого періоду. Вона визначається обсягами продажу і контролюється постійним дослідженням ринку. Такі стадії, як вихід на ринок, зростання, зрілість, насичення і падіння, дають змогу передбачити зміни у смаках споживачів, канали розподілу. Як індикатори, що відображають стадію виробничого циклу, використовують показники обсягів реалізації продукції й отриманий прибуток.

Однак далеко не всі господарства в умовах недостатнього фінансування можуть впроваджувати нові прогресивні розробки. Разом з тим, окремі господарства працюють 3 певним прибутком, застосовуючи комплекс інтенсифікаційних заходів за різних технологій ведення рибництва.

Для кількісного виміру рентабельності в цілому по аграрних підприємствах використовують такі три традиційні показники: рівень рентабельності, норму прибутку і приведену до земельної площі масу прибутку. 3 переходом до ринкової економіки і зростанням конкуренції на внутрішньому і зовнішньому ринках дуже важливо для оцінки економічної ефективності виробництва визначати такий показник, як рентабельність продажу.

Протягом всього періоду вирощування рибі згодовували комбікорми Aller Aqua, Датського та Польського виробництва, які закуплялись при допомозі польсько-української фірми “Форель”. На початкових етапах годівлі використовували стартові корми, надалі їх згодовували згідно температури води, маси риби та величини гранули.

\section{Висновки}

Проведені дослідження за оцінкою ефективності вирощування товарної форелі при годівлі кормами Aller Aqua показали, що кормовий коефіцієнт знаходиться в межах одиниці, а собівартість 1 кг корму становила 50,3 грн і на вирощування форелі до товарної маси в межах 320-350 г затрати на корми складають більше $70 \%$ від усіх витрат.

Продаж риби споживачам відбувався за ціною 135 грн/кг в результаті виробництво рибної продукціїі $\epsilon$ прибутковим, а рентабельність відповідно становила $54,15 \%$.

Перспективи подальших досліджень Нами будуть продовжені дослідження, спрямовані на порівняльну оцінку кормів Aller aqua, їх використання у інших господарствах для вирощування форелі. А також буде здійснюватись розрахунок економічної ефективності ведення господарства. Окрім цього проводяться дос- лідження щодо впливу цих кормових засобів на функціональний стан росту і розвитку форелі, іхтіологічні та біохімічні показники рибопродуктивності.

\section{References}

Brinker, A., Nielsen, R., \& Rad, F. (2016). Establishing a benchmarking for fish farming - Profitability, productivity and energy efficiency of German, Danish and Turkish rainbow trout grow-out systems. Aquaculture researche, 48(6), 3134-3148. doi: 10.1111/are.13144.

Bozhyk, V., Bulatovych, M., Hrekh, V., \& Tsymbala, H. (2004). Intensyvne vyroshchuvannia posadkovoho materialu raiduzhnoi foreli $\mathrm{v}$ rybohospodarstvakh Ukrainskykh Karpat. Silskyi hospodar, 3-4, 31-35 (in Ukrainian).

Hrynzhevskyi, M.V., Omelchuk, Yu.A., Buriak, I.V., \& Horai, N.O. (2002). Vplyv deiakykh faktoriv na pidvyshchennia efektyvnosti vyroshchuvannia tovarnoi ryby. Tavriiskyi naukovyi visnyk, 22, 251256 (in Ukrainian).

Mamchych, T.I. (2006). Statystychnyi analiz danykh z paketom STATISTICA. Drohobych: Vydavnycha firma "Vidrodzhennia" ( in Ukrainian).

Martseniuk, N.O. (2008). Ekonomichna efektyvnist vyroshchuvannia tovarnoi ryby $\mathrm{u}$ fermerskykh hospodarstvakh Lvivskoi oblasti. Rybohospodarska nauka Ukrainy, 3, 63-67. doi: 10.15407/fsu (in Ukrainian).

Pivtorak, Ya.I., Bobel, I.Yu., \& Bozhyk, O.V. (2017). Perspektyvy vykorystannia kormiv "Aller aqua" u zhyvlenni raiduzhnoi foreli. Naukovyi visnyk Lvivskoho natsionalnoho universytetu veterynarnoi medytsyny ta biotekhnolohii imeni S. Z. Gzhytskoho. Seriia : Silskohospodarski nauky, 19(74), 95-98. doi: 10.15421/nvlvet74 (in Ukrainian).

Pivtorak, Ya.I., \& Bobel, I.Yu. (2018). Stratehiia efektyvnosti hodivli foreli kormamy Aller aqua. Naukovyi visnyk Lvivskoho natsionalnoho universytetu veterynarnoi medytsyny ta biotekhnolohii imeni S.Z. Gzhytskoho, 20(84), 88-92. doi: 10.15421/nvlvet8416 (in Ukrainian).

Pivtorak, Ya.I., \& Bobel, I.Yu. (2017). Intensyvnist rostu i rozvytku raiduzhnoi foreli za vykorystannia kormiv Aller Aqua ta Aquafeed Fischfutter. Naukovyi visnyk Lvivskoho natsionalnoho universytetu veterynarnoi medytsyny ta biotekhnolohii imeni S.Z. Gzhytskoho, 19(79), 73-77. doi: 10.15421/nvlvet79 (in Ukrainian).

Pivtorak, Ya.I., \& Bobel, I.Yu. (2017). Vykorystannia kormiv "Aller aqua" u hodivli raiduzhnoi foreli v PP "Zakhidna rybna kompaniia". Ahrarna nauka ta kharchovi tekhnolohii, 2, 3-9. http://nbuv.gov.ua/UJRN/ anxt_2017_2_3 (in Ukrainian). 